\title{
Thigh haematoma following acupuncture treatment in a patient on warfarin
}

\author{
Sami Kenz, Hayley Webb, Steven Laggan \\ Department of Diabetes and Endocrinology, Trafford General Hospital, Manchester, UK
}

Correspondence to Dr Sami Kenz, samikenz71@yahoo.co.uk

\section{DESCRIPTION}

A 82-year-old woman on warfarin for atrial-fibrillation was admitted via the acute medical take having developed a large haematoma in the right thigh (picture). She gave a history of recent acupuncture treatment for trochanteric bursitis. Acupuncture treatment had been given in the community and we do not know if the therapist was aware of the fact she was being treated with warfarin, nor do we know if enquiry was made about the state of anticoagulant control at the time of needle insertion. Retrospective examination of the anticoagulant clinic records revealed that her international normalized ration (INR) was 2.4 at the time of needle insertion.

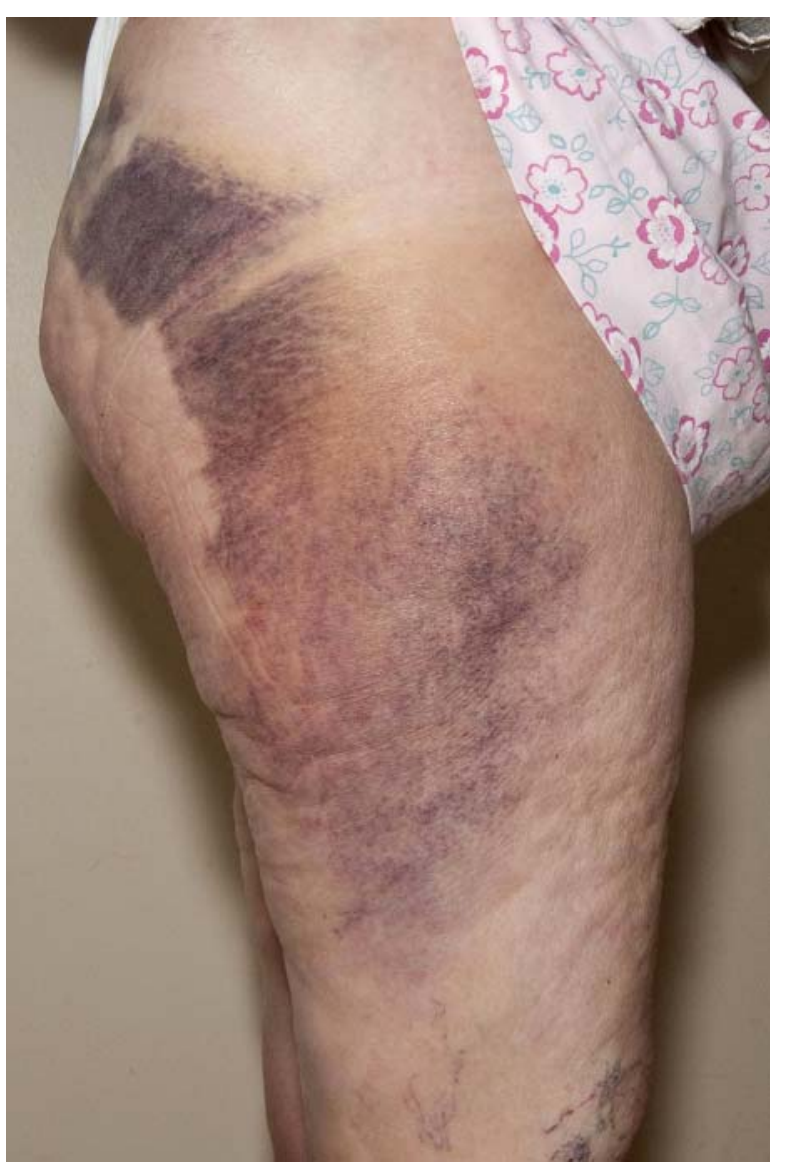

Ultrasound scan confirmed that the haematoma extended deeply into the right buttock and upper thigh.

Her haemoglobin dropped to $8.7 \mathrm{~g} / \mathrm{dl}$ compared to $12.1 \mathrm{~g} / \mathrm{dl}$ before acupuncture therapy. Her INR was 2.2 on the day of admission, she was on stable dose of warfarin and there was no concomitant drug interaction.

Warfarin was stopped and she was given oral vitamin $\mathrm{K}$ to reverse her INR, she did not require a blood transfusion. She made a good recovery and her haematoma has gradually resolved.

The rationale for using warfarin was reviewed (repeated ECG was sinus rhythm) and a decision was taken to withhold further warfarin therapy.

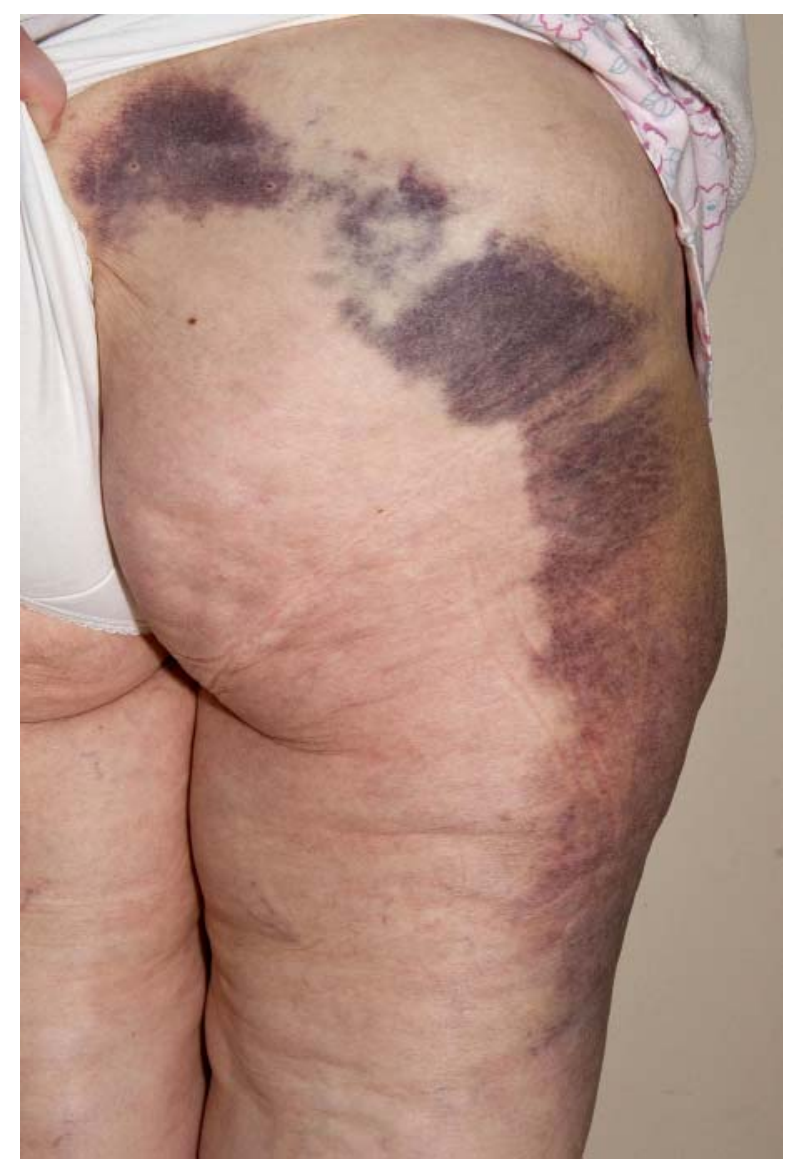




\section{BMJ Case Reports}

Acupuncture is widely practised in developed health economies. ${ }^{1}$ It is estimated that $2.5-10 \%$ of the UK population receive non-conventional treatments ('alternative therapy') each year and that only $10 \%$ of these are via referral in the NHS. ${ }^{2}$ Acupuncture is the most commonly used of the nonconventional treatments. Acupuncture can be associated with serious adverse events like bleeding and subcutaneous haematoma $6.1 \%{ }^{3}$

\section{Learning points}

- Acupuncture can be associated with serious adverse events like subcutaneous haematoma especially in patients on warfarin.

- Acupuncture should be used with caution in patients on warfarin.
Competing interests None.

Patient consent Obtained.

\section{REFERENCES}

1. NIH Consensus Development Program (Vol. 15). http://odp.od.nih.gov/ consensus/cons/107/107 intro.htm (accessed November 1997).

2. Jonathan R, David M. Mapping the evidence base and use of acupuncture within the NHS. West Midlands Health Technology, Assessment Collaboration, Department of Public Health and Epidemiology, Birmingham: The University of Birmingham 2006.

3. Witt CM, Pach D, Brinkaus B, et al. Safety of acupuncture: results of a prospective observational study. Forsch Komplement 200916:91-7.

Copyright 2012 BMJ Publishing Group. All rights reserved. For permission to reuse any of this content visit http://group.bmj.com/group/rights-licensing/permissions.

BMJ Case Report Fellows may re-use this article for personal use and teaching without any further permission.

Please cite this article as follows (you will need to access the article online to obtain the date of publication).

Kenz S, Webb H, Laggan S. Thigh haematoma following acupuncture treatment in a patient on warfarin. BMJ Case Reports 2012;10.1136/bcr-2012-006676, Published XXX

Become a Fellow of BMJ Case Reports today and you can:

- Submit as many cases as you like

- Enjoy fast sympathetic peer review and rapid publication of accepted articles

- Access all the published articles

- Re-use any of the published material for personal use and teaching without further permission

For information on Institutional Fellowships contact consortiasales@bmjgroup.com

Visit casereports.bmj.com for more articles like this and to become a Fellow 